\title{
ANALISIS KAUSALITAS KEPUTUSAN INVESTASI, PEMBIAYAAN DAN DIVIDEN PADA PERUSAHAAN ASURANSI
}

\author{
Sutrisno \\ Fakultas Ekonomi \\ Universitas Islam Indonesia \\ Yuana \\ Alumnus Program Magister Management \\ Universitas Islam Indonesia
}

\begin{abstract}
The study aims at analyzing the causal relationship of decision-making concerning investment, financing from retained earning and dividend of insurance corporations at Jakarta Stock Exchange. The rationale of choosing this subject because of unique factor from industry and the tendency of insurance industries as a large business, which reach the world in the future.

Result of this research is expected to give input for Insurance Corporations Management to be wiser in determining the investment of decision making, financing from retained earning and dividend, especially in dividend payment and the hold profit increasing in financing patterns.

The research result on the causality among the tree variables indicates that insurance corporations in Jakarta Stock Exchange are within the fist theory Miller and Modigliani he said the decision of dividend no influence to value of corporation and also capital expense. The causality between decision-making concerning investment, financing from retained earning and dividend is not always absolute for the research made on homogen markets relatively.
\end{abstract}

\section{PENDAHULUAN}

Keputusan strategi manajemen keuangan yang tak dapat diabaikan ialah masalah bagaimana pihak manajemen mengambil keputusan untuk investasi, dividen dan pembiayaan, yang terkait erat dengan optimalisasi nilai dan pertumbuhan perusahaan. Masalah tersebut pada umumnya didekati dengan menggunakan analisis kuantitatif mengenai struktur keuangan melalui pendekatan ekonometrik yang menyangkut hubungan kausalitas antara keputusan investasi, deviden dan pembiayaan perusahaan. Meskipun pendekatan kualitatif mengenai analisis perilaku (Behavioral Analysis) terhadap perilaku pengambilan keputusan manajerial perusahaan penting untuk dilakukan, namun dalam penelitian ini, karena keterbatasan waktu pendekatan tersebut tidak dilakukan, dan dibatasi hanya pada aspek kuantitatif melalui analisis ekonometrik untuk mengetahui hubungan kausalitas antara keputusan investasi, dividen dan pembiayaan pada perusahaan asuransi yang listing di Bursa Efek Jakarta. 
Jacob dan Pettit (1989) mengatakan: "Maximization of value by choice of invesment, financing, and deviden decisions of how those decisions impact upon expected future cash flow, risk, and thus the equilibrium expected return". Pendapat ini menekankan bahwa maksimalisasi nilai perusahaan bergantung pada pilihan berbagai keputusan mengenai investasi, pembiayaan, dan dividen yang merupakan fungsi bagaimana keputusan berdampak pada harapan arus kas masa depan, resiko, dan keseimbangan harapan pengembalian (expected return) dari biaya atau modal yang dikeluarkan. Weston dan Brigham (1994) mengatakan bahwa kebijakan deviden yang optimal (optimal dividen policy), yaitu kebijakan dividen yang menekankan keseimbangan antara deviden saat ini (current) dan pertumbuhan pada masa mendatang (future growth) sehingga memaksimumkan harga saham perusahaan. Demikian pula penelitian yang dilakukan oleh Mukherjee dan Mboja (1994) melalui studi informasi asimetri menyatakan bahwa keputusan investasi sebuah perusahaan bergantung pada keputusan dividen dan pembiayaan perusahaan.

Penelitian ini didasarkan pada dua pandangan teori kebijakan deviden yang saling bertentangan. Keduanya berkaitan dengan keputusan investasi. Teori yang pertama dikumandangkan oleh Miller dan Modigliani (1958, dalam bukunya Suad Husnan, 1992) yang menyatakan bahwa kebijakan deviden perusahaan tidak ada pengaruhnya terhadap nilai perusahaan maupun biaya modal, teori ini dikenal sebagai teori ketidak relevanan deviden (dividend irrelevance theory). (Sutrisno, 1996). Sedangkan teori kedua dinyatakan oleh Gordon (1963) yang menyatakan bahwa kebijakan deviden berpengaruh terhadap nilai perusahaan, tetapi resiko deviden tidak sebesar risiko kenaikan nilai modal sehingga suatu perusahaan dapat menetapkan suatu rasio pembagian dividen yang tinggi dan menawarkan hasil dividen yang tinggi guna meminimumkan biaya modalnya.

Pendapat ini bagi Miller dan Modigliani sebagai kekeliruan bird in the hand, yang sewaktu-waktu dapat terbang. Namun yang perlu dipertimbangkan adalah asumsi-asumsi yang dilakukan oleh Miller dan Modigliani dengan alasan teori yang terkendali (manageable), yaitu: (1) Tidak terdapat pajak pribadi dan pajak perusahaan; (2) Tidak terdapat biaya emisi atas jual beli saham; (3) Tidak adanya pengaruh leverage keuangan terhadap biaya modal; (4) Investor dan manajer mempunyai informasi yang sama tentang prospek perusahaan; (5) Distribusi pendapatan dan di antara dividen dan laba yang ditahan tidak mempunyai pengaruh terhadap biaya ekuitas perusahaan. Apakah asumsi - asumsi itu tepat dan dapat dilaksanakan dalam kenyataan praktis?

Disinilah perdebatan akademis dari dua teori di atas. Selain kedua teori di atas, juga penelitian yang dilakukan oleh Mukherjee \& Mboja (1994) 
dan Made Sudarma (1997) yang menyelidiki hubungan kausalitas antara keputusan dividen, investasi, dan pembiayaan pada perusahaan manufactur. Dimana hasil penelitian sebelumnya mengandung unsur kelemahan dengan tidak dapat dijelaskannya jenis investasi dan jenis pembiayaan apa yang berpengaruh terhadap kebijakan tersebut, sehingga dari hasil yang diperoleh masih mungkin terjadi kesalahan penafsiran terhadap jenis variabel yang mempengaruhi ketiga kebijakan tersebut.

Memandang pentingnya jenis variabel tersebut dimasukkan dalam penelitian untuk menguji hubungan antar ketiga kebijakan tersebut, maka pada variabel bebas penelitian ini akan dibahas setiap jenisnya. Jenis investasi akan dibagi menjadi investasi riel dan investasi financial, dan jenis pembiayaan dibagi menjadi tiga yaitu: pembiayaan yang berasal dari laba yang ditahan, pembiayaan yang berasal dari modal saham, dan pembiayaan yang berasal dari hutang jangka panjang. Dari pemaparan di atas peneliti tertarik untuk mengetahui hubungan kausalitas dua arah antara keputusan investasi, pembiayaan dan dividen pada perusahaan asusransi.

\section{METODE PENELITIAN}

\section{Sumber Data}

Sumber data yang digunakan dalam penelitian ini adalah data sekunder yang bersumber dari Indonesia Capital Market Directory, dan sumber-sumber lain yang terkait yaitu Laporan Bursa Efek Jakarta, Laporan Manajemen, dan JSX Statistics. Data yang digunakan untuk penelitian ini adalah: perkembangan investasi riil, investasi financial, pembiayaan dari laba yang ditahan, pembiayaan dari penambahan saham baru, pembiayaan dari hutang, dan dividen kas perusahaan asuransi untuk periode 1995 s.d 2001.

\section{Populasi dan Sample Penelitian}

Populasi dalam penelitian ini adalah perusahaan asuransi yang go publik di Bursa Efek Jakarta. Sampel yang ditetapkan adalah perusahaan asuransi di Bursa Efek Jakarta yang telah listing sejak tahun 1995-2001 (7 Tahun). Perusahaan asuransi yang memenuhi kriteria tersebut ada 10 perusahaan dari 11 perusahaan asuransi yang listing di Bursa Efek Jakarta. Perusahaan asuransi ke sebelas (Lipo General Insurance) tidak dimasukkan dalam penelitian karena baru listing di Bursa Efek Jakarta pada tahun 1997 (6 tahun). 


\section{Variabel Penelitian}

- Investasi (investment) dengan notasi (INV), dihitung secara agregat meliputi investasi riil yang diperoleh dari nilai bersih asset tetap perusahaan asuransi (Fixed Assets - Net), sedangkan asset financial diperoleh dari investasi jangka panjang perusahaan asuransi dalam bentuk surat berharga (Investment).

- Dividen (dividend) dengan notasi DIV, adalah kas yang dibayarkan secara teratur dalam periode tertentu (tahunan) oleh perusahaan kepada pemegang saham. Nilai dividen yang digunakan adalah dividen kas yang dibagikan setiap tahun selama 7 tahun (periode 1995 - 2001).

- Pembiayaan (financing) dengan notasi FIN, dihitung secara agregat meliputi laba yang ditahan (LDT atau Retained Earnings), penambahan saham baru (MDS atau Paid-up capital + Paid-up capital in excess of par value), dan hutang jangka panjang (HJP atau Premium and Claim Reserves). Hutang jangka panjang perusahaan asuransi terdiri dari premi yang ditangguhkan dan hutang jangka panjang lainnya yang diterbitkan oleh perusahaan asuransi, misalnya dalam bentuk obligasi. Pada umumnya sebagian besar hutang jangka panjang perusahaan asuransi berupa premi asuransi yang ditangguhkan.

\section{Model Penelitian}

Penelitian ini menggunakan analisis yang didasarkan pada laporan keuangan dengan melakukan tabulasi variabel investasi, dividen dan pembiayaan selama 7 tahun dari 10 sample perusahaan asuransi. Disamping itu juga menggunakan alat ekonometrik dengan test kausalitas Greger dan Vector aouregressive (VAR), dengan bantuan program Eveiws Versi 3.0.

\section{Uji Granger}

Adakalanya seorang peneliti memasukkan waktu sebagai salah satu variabel bebas. Hal ini dilakukannya karena dia menduga ada kemungkinan terdapat perubahan yang otonom terjadi pada koefisienkoefisien variabel bebas yang diakibatkan oleh trend waktu sehingga terjadi perubahan yang otonom pada dependent variabel. Untuk itu, digunakan model Granger dengan formulasi sebagai berikut:

dimana $\mathrm{T}=$ waktu

$$
\mathrm{Y}_{\mathrm{t}}=\beta_{0}+\beta_{1} \mathrm{X}_{1 \mathrm{t}}+\beta_{2} \mathrm{X}_{2 \mathrm{t}}+\beta_{3} \mathrm{X}_{\mathrm{n}}+\mathrm{T}+\varepsilon_{\mathrm{t}}
$$

$\beta_{0,} \beta_{1,} \beta_{2,} \beta_{n}=$ Koefisien regresi

$\mathrm{Y}_{t} \quad=$ Variabel INV, FIN LDT dan DIV.

$\mathrm{X}_{t} \quad=$ Variabel INV, FIN LDT dan DIV

$\varepsilon_{t} \quad=$ error terms 


\section{Vector Autoregressive Technique (VAR Tehcnique)}

Kritik utama yang dilontarkan terhadap pengujian kausalitas yang telah dikemukan oleh Greger ialah panjang time-lag ditentukan secara arbitrer sehingga tidak menjamin tidak adanya korelasi serial (autokorelasi) pada error terms. Untuk itu Hasio $(1979,1981)$ dalam Sritua (1993), mengemukakan metode Vector Autoregression Technique (VAR Technique) sebagai pelengkap metode Greger. Menurut Gujarati(1998) salah satu kelemahan metode VAR adalah koefisien variabel secara individual sulit diinterprestasikan, dan lag variabel independen exogen berlawan arah dengan variabel dependen.

\section{Penaksiran Model Regresi yang Autoregressive}

Penaksiran model regresi yang autoregressive tidak bisa ditaksir dengan metode regresi linier klasik karena dalam model ini terdapat kemungkinan adanya variabel-variabel bebas yang sthochastic dan korelasi serial di antara error term. Adapun metode yang telah direkomendasikan untuk penksiran model regresi yang autoregressive adalah metode variabel instrumental (Arief, Sritua :1993; 47).

Metode variabel instrumental ini kendatipun dapat merupakan metode penaksiran koefisien regresi untuk model yang autoregressive, tetapi metode ini tidak dapat memecahkan masalah autokorelasi yang mungkin terdapat pada error terms model regresi ini. Oleh sebab itu, telah diusulkan untuk menggunakan metode General Least Squares (GLS).

Berdasarkan persamaan dari langkah satu dan dua maka diperoleh model regresi autoregresive sebagai berikut:

口 Hubungan antara keputusan investasi dengan pembiayaan

$$
\begin{aligned}
& \mathrm{INV}_{\mathrm{t}}=\alpha+\sum_{\mathrm{i}=1}^{\mathrm{m}} \alpha_{\mathrm{i}} \operatorname{INV}_{\mathrm{t}-\mathrm{i}}+\alpha_{\mathrm{i}} \mathrm{FIN}_{\mathrm{t}}+\sum_{\mathrm{i}=1}^{\mathrm{m}} \alpha_{\mathrm{i}} \mathrm{FIN}_{\mathrm{t}-\mathrm{i}}+\varepsilon_{\mathrm{t}} \\
& \mathrm{FIN}_{\mathrm{t}}=\beta+\sum_{\mathrm{i}=1}^{\mathrm{m}} \beta_{\mathrm{i}} \mathrm{FIN}_{\mathrm{t}-\mathrm{i}}+\beta_{\mathrm{i}} \mathrm{INV}_{\mathrm{t}}+\sum_{i=1}^{\mathrm{m}} \beta_{i} \mathrm{INV}_{\mathrm{t}-\mathrm{i}}+\varepsilon_{\mathrm{t}}
\end{aligned}
$$

- Hubungan antara keputusan pembiayaan dari laba ditahan dengan dividen

$$
\begin{aligned}
& \text { FINLDT }_{\mathrm{t}}=\alpha+\sum_{\mathrm{i}=1}^{\mathrm{m}} \alpha_{\mathrm{i}} \text { FIN LDT }_{\mathrm{t}-\mathrm{i}}+\alpha_{\mathrm{i}} \text { DIV }_{\mathrm{t}}+\sum_{\mathrm{i}=1}^{\mathrm{m}} \alpha_{\mathrm{i}} \text { DIV }_{\mathrm{t}-\mathrm{i}}+\varepsilon_{\mathrm{t}} \\
& \text { DIV }_{\mathrm{t}}=\beta+\sum_{\mathrm{i}=1}^{\mathrm{m}} \beta_{\mathrm{i}} \text { DIV }_{\mathrm{t}-\mathrm{i}}+\beta_{\mathrm{i}} \text { FIN LDT }_{\mathrm{t}}+\sum_{\mathrm{i}=1}^{\mathrm{m}} \beta_{\mathrm{i}} \text { FIN LDT }_{\mathrm{t}-\mathrm{i}}+\varepsilon_{\mathrm{t}}
\end{aligned}
$$

- Hubungan antara keputusan investasi dengan dividen

$$
\mathrm{INV}_{\mathrm{t}}=\alpha+\sum_{\mathrm{i}=1}^{\mathrm{m}} \alpha_{\mathrm{i}} \mathrm{INV}_{\mathrm{t}-\mathrm{i}}+\alpha_{\mathrm{i}} \mathrm{DIV}_{\mathrm{t}}+\sum_{\mathrm{i}=1}^{\mathrm{m}} \alpha_{i} \mathrm{DIV}_{\mathrm{t}-\mathrm{i}}+\varepsilon_{\mathrm{t}}
$$




$$
\operatorname{DIV}_{\mathrm{t}}=\beta+\sum_{\mathrm{i}=1}^{\mathrm{m}} \beta_{\mathrm{i}} \operatorname{DIV}_{\mathrm{t}-\mathrm{i}}+\beta_{\mathrm{i}} \mathrm{INV}_{\mathrm{t}}+\sum_{\mathrm{i}=1}^{\mathrm{m}} \beta_{\mathrm{i}} \mathrm{INV}_{\mathrm{t}-\mathrm{i}}+\varepsilon_{\mathrm{t}}
$$

\section{Pengujian Hipotesis}

Uji $t$

Uji t digunakan untuk menguji signifikansi pengaruh parsial variabel independent terhadap variabel dependent, dengan hipotesa sebagai berikut:

$$
\mathrm{t}_{\text {hit }}=\frac{\beta_{\mathrm{i}}}{\operatorname{se} \beta_{\mathrm{i}}}
$$

Dimana:

$\beta_{\mathrm{i}} \quad=$ Koefisien Regresi

se $\beta_{\mathrm{i}} \quad=$ Standar Error Koefisien Regresi

Ho: $\beta_{\mathrm{i}}=0$, artinya tidak ada pengaruh yang nyata dari variabel independent terhadap variabel dependent secra individu.

$\mathrm{Ha}: \beta_{\mathrm{i}} \neq 0$, artinya ada pengaruh yang nyata dari variabel independent terhadap variabel dependent secara individu.

Sedangkan $\alpha=5 \%, \mathrm{df}=\mathrm{n}-\mathrm{k}-1$

$\mathrm{t}_{\text {hit }}>\mathrm{t}_{\text {tabel }}$, Ho ditolak, Ha diterima

$\mathrm{t}_{\text {hit }} \leq \mathrm{t}_{\text {tabel }}$, Ho diterima, Ha ditolak

Untuk memperkuat indikasi keberadaan berbagai bentuk kausalitas diatas, maka dilakukan $\mathrm{F}_{\text {test }}$ untuk masing-masing model regresi.

Uji F

Uji F digunakan untuk menguji signifikansi pengaruh variabel independent terhadap variabel dependent secara bersamaan, dengan hipotesa sebagai berikut:

Ho : $\beta_{\mathrm{i}}=0$, artinya tidak ada pengaruh yang nyata dari variabel independent terhadap variabel dependent secara keseluruhan.

$\mathrm{Ha}: \beta_{\mathrm{i}} \neq 0$, artinya ada pengaruh yang nyata dari variabel independent terhadap variabel dependent secara keseluruhan.

\section{Uji F GLS (General Least Squares)}

Dari hasil regresi bentuk model regresi linier diperoleh nilai $F$ hit sebagai berikut:

$$
\mathrm{F}_{\text {hit }}=\frac{\operatorname{Rur}-\mathrm{Rr}^{2} / \mathrm{k}}{\left(\operatorname{Rur}^{2}\right) /(\mathrm{n}-\mathrm{k})}
$$

Dimana:

Rur $^{2}=$ R Square unrestricted 


$$
\begin{aligned}
& \mathrm{Rr}^{2} \quad=\mathrm{R} \text { Square restricted } \\
& \mathrm{n} \quad=\text { Banyaknya data } \\
& \mathrm{k} \quad=\text { Banyaknya variabel independent } \\
& \text { sedangkan } \mathrm{F} \text { tabel ditentukan dengan } \alpha=5 \%, \mathrm{df}=(\mathrm{n}-\mathrm{k}-1) \\
& \mathrm{F}_{\text {hit }}>\mathrm{F}_{\text {tabel }}, \text { Ho ditolak, Ha diterima signifikan } \\
& \mathrm{F}_{\text {hit }} \leq \mathrm{F}_{\text {tabel }}, \text { Ho diterima, Ha ditolak tidak signifikan }
\end{aligned}
$$

HASIL PENELITIAN

Tabel 1. Hasil perhitungan Uji Greger untuk kausalitas menggunakan pooling data langkah satu

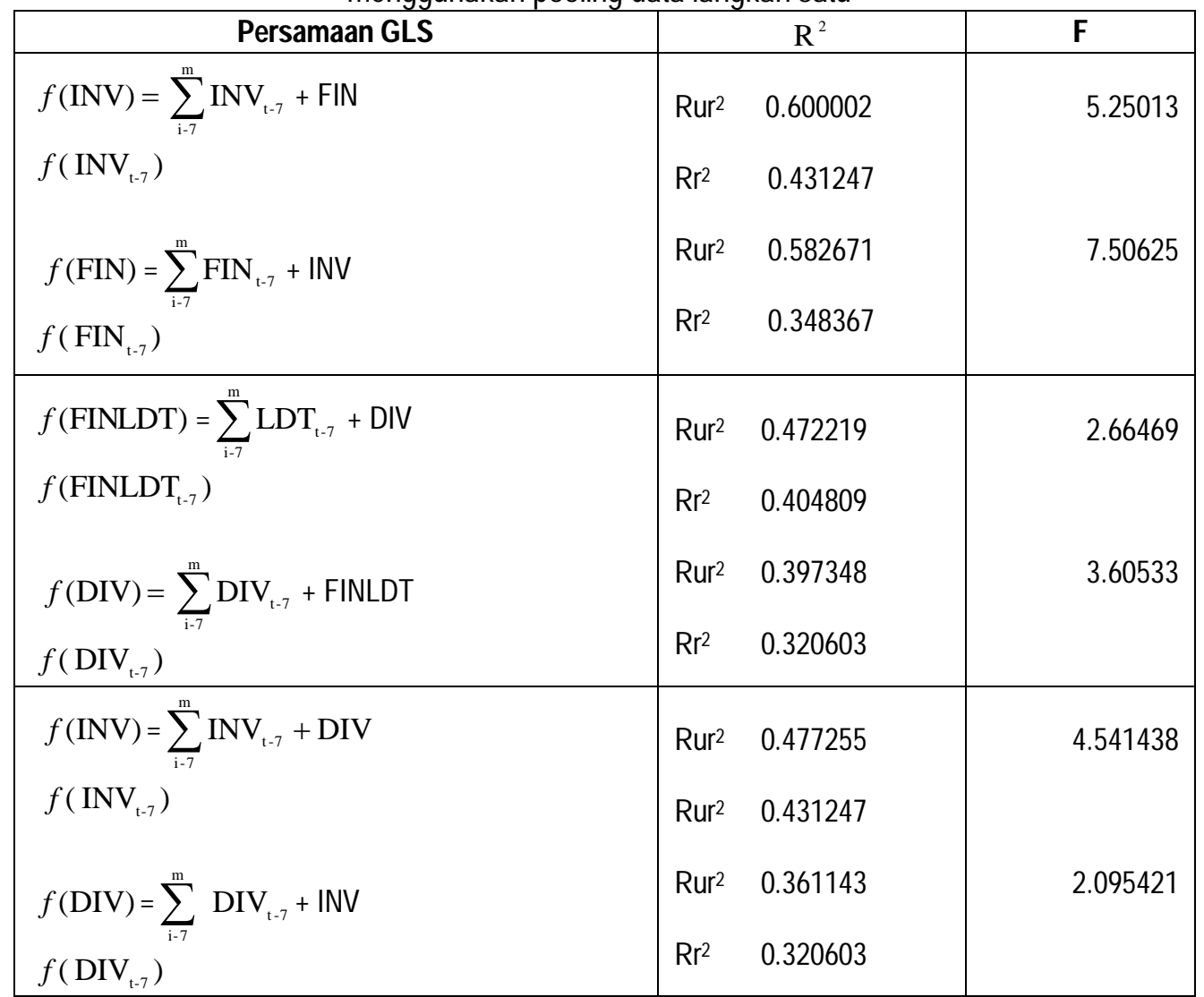

Sumber lampiran $4 \mathrm{~s} . \mathrm{d} 12$

F tabel $(6.63) ; 1 \%=3.12 ; 5 \%=2.25 ; 10 \%=1.87$ 
Berdasarkan dari tabel 1 hubungan antara investasi dengan pembiayaan, diketahui bahwa Rur $^{2}$ ( $R$ square unrestricted) investasi ke pembiayaan adalah 0,600002. Hal ini berarti $60 \%$ investasi dapat dijelaskan oleh variabel pembiayaan dengan time lag 7 tahun. Sedangkan sisanya $(100 \%-60 \%=40 \%)$ dijelaskan oleh oleh sebab-sebab yang lain. Sedangkan fungsi investasi dengan time lag 7 tahun diketahui sebesar 0,43127 ( $\mathrm{Rr}^{2} / \mathrm{R}$ square restricted). Berdasarkan persamaan $\mathrm{Rur}^{2}$ dan $\mathrm{Rr}^{2}$ diperoleh hasil $F_{\text {stat }}$ sebesar 5.25013. Berdasarkan uji $F$ diketahui bahwa $\mathrm{F}_{\text {stat }}>\mathrm{F}_{\text {tabel }} \quad(5.25013>3.12)$ pada tingkat signifikan 1\%, tolak $\mathrm{H}_{0}$, terima $\mathrm{H}_{\mathrm{a}}$ signifikan artinya ada hubungan yang nyata dari variabel pembiayaan terhadap variabel investasi secara keseluruhan. Sebaliknya hubungan antara pembiayaan dengan investasi, diketahui bahwa Rur ${ }^{2}$ ( $R$ square unrestricted) pembiayaan ke investasi adalah 0,582671. Hal ini berarti $58 \%$ pembiayaan dapat dijelaskan oleh variabel investasi dengan time lag 7 tahun. Sedangkan sisanya $(100 \%-58 \%=42 \%)$ dijelaskan oleh oleh sebab-sebab yang lain. Sedangkan fungsi pembiayaan dengan time lag 7 tahun diketahui sebesar 0,348367 ( $\mathrm{Rr}^{2} / \mathrm{R}$ square restricted). Berdasarkan persamaan $\mathrm{Rur}^{2}$ dan $\mathrm{R}^{2}$ diperoleh hasil $\mathrm{F}_{\text {stat }}$ sebesar 7.50625. Berdasarkan uji $F$ diketahui bahwa $\mathrm{F}_{\text {stat }}>\mathrm{F}_{\text {tabel }}(7.50625>3.12)$ dengan tingkat signifikan $1 \%$, tolak $\mathrm{H}_{0}$, terima $\mathrm{H}_{\mathrm{a}}$ signifikan artinya ada hubungan yang nyata dari variabel investasi terhadap variabel pembiayaan secara keseluruhan.

Pada kolom dua hubungan antara pembiayaan dari laba ditahan dengan dividen, diketahui bahwa Rur ${ }^{2}$ (R square unrestricted) pembiayaan dari laba ditahan adalah 0,472219 . Hal ini berarti $47 \%$ pembiayaan dari laba ditahan dapat dijelaskan oleh variabel pembiayaan dengan time lag 7 tahun. Sedangkan sisanya $(100 \%-47 \%=53 \%)$ dijelaskan oleh oleh sebab-sebab yang lain. Sedangkan fungsi investasi dengan time lag 7 tahun diketahui sebesar 0,404809 ( $\mathrm{Rr}^{2} / \mathrm{R}$ square restricted). Berdasarkan persamaan $\operatorname{Rur}^{2}$ dan $\mathrm{Rr}^{2}$ diperoleh hasil $\mathrm{F}_{\text {stat }}$ sebesar 2.66469. Berdasarkan uji $F$ diketahui bahwa $\mathrm{F}_{\text {stat }}>\mathrm{F}_{\text {tabel }} \quad(2.66469>2.25)$ pada tingkat signifikan $5 \%$, tolak $H_{0}$, terima $H_{a}$ signifikan artinya ada hubungan yang nyata dari variabel pembiayaan dari laba ditahan terhadap variabel dividen secara keseluruhan. Sebaliknya hubungan antara dividen dengan pembiayaan dari laba ditahan, diketahui bahwa Rur $^{2}$ ( $R$ square unrestricted) dividen ke pembiayaan dari laba ditahan adalah 0,397348 . Hal ini berarti $40 \%$ dividen dapat dijelaskan oleh variabel pembiayaan dengan time lag 7 tahun. Sedangkan sisanya $(100 \%-40 \%=60 \%)$ dijelaskan oleh oleh sebab-sebab yang lain. Sedangkan fungsi dividen dengan time lag 7 tahun diketahui sebesar 0,320603 ( $\mathrm{Rr}^{2}$ / R square restricted). Berdasarkan persamaan Rur ${ }^{2}$ dan $\mathrm{Rr}^{2}$ diperoleh hasil $\mathrm{F}_{\text {stat }}$ sebesar 3.60533. Berdasarkan uji $\mathrm{F}$ diketahui 
bahwa $\mathrm{F}_{\text {stat }}>\mathrm{F}_{\text {tabel }}(3.60533>2.25)$ dengan tingkat signifikan $5 \%$, tolak $\mathrm{H}_{0}$, terima $\mathrm{H}_{\mathrm{a}}$ signifikan artinya ada hubungan yang nyata dari variabel dividen terhadap variabel pembiayaan dari laba ditahan secara keseluruhan.

Hubungan antara investasi dengan dividen, diketahui bahwa Rur ${ }^{2}$ (R square unrestricted) investasi ke dividen adalah 0.477255 . Hal ini berarti $47,7 \%$ investasi dapat dijelaskan oleh variabel dividen dengan time lag 7 tahun. Sedangkan sisanya $(100 \%-47,7 \%=52,3 \%)$ dijelaskan oleh oleh sebab-sebab yang lain. Sedangkan fungsi investasi dengan time lag 7 tahun diketahui sebesar 0,43127 ( $\mathrm{Rr}^{2} / \mathrm{R}$ square restricted). Berdasarkan persamaan $\operatorname{Rur}^{2}$ dan $\mathrm{Rr}^{2}$ diperoleh hasil $\mathrm{F}_{\text {stat }}$ sebesar 4.541438. Berdasarkan uji $F$ diketahui bahwa $\mathrm{F}_{\text {stat }}>\mathrm{F}_{\text {tabel }} \quad(4.541438>3.12)$ pada tingkat signifikan $1 \%$, tolak $H_{0}$, terima $H_{a}$ signifikan artinya ada hubungan yang nyata dari variabel investasi terhadap variabel dividen secara keseluruhan. Sebaliknya hubungan antara dividen dengan investasi, diketahui bahwa Rur ${ }^{2}(R$ square unrestricted) dividen ke investasi adalah 0,361143. Hal ini berarti $36 \%$ dividen dapat dijelaskan oleh variabel investasi dengan time lag 7 tahun. Sedangkan sisanya $(100 \%-36 \%=64 \%)$ dijelaskan oleh oleh sebab-sebab yang lain. Sedangkan fungsi dividen dengan time lag 7 tahun diketahui sebesar 0,320603 ( $\mathrm{Rr}^{2} / \mathrm{R}$ square restricted). Berdasarkan persamaan $\mathrm{Rur}^{2}$ dan $\mathrm{Rr}^{2}$ diperoleh hasil $\mathrm{F}_{\text {stat }}$ sebesar 2.095421. Berdasarkan uji $F$ diketahui bahwa $\mathrm{F}_{\text {stat }}>\mathrm{F}_{\text {tabel }} \quad(2.095421>1.87)$ dengan tingkat signifikan $10 \%$, tolak $H_{0}$, terima $H_{a}$ signifikan artinya ada hubungan yang nyata dari variabel dividen terhadap variabel investasi secara keseluruhan.

Kesimpulan hasil tabel 1 secara keseluruhan berdasarkan uji $F$ bahwa terdapat hubungan antara investasi dengan pembiayaan, pembiayaan dari laba ditahan dengan dividen dan investasi dengan dividen secara keseluruhan.

Adapun untuk melihat seberapa besar serta arah pengaruhnya maka dapat dilihat pada tabel 2.

Persamaan GLS pada kolom 1 hubungan antara investasi dengan pembiayaaan, dimana $\beta_{i}$ (koefisien regresi) investasi 1.175364 yang menyatakan bahwa setiap penambahan (karena tanda +) Rp 1 akan menaikkan pembiayaan sebesar Rp 1.175364. Begitu juga dengan $\beta_{i}$ (koefisien regresi) pembiayaan 1.81537, yang menyatakan bahwa setiap penambahan Rp 1 akan menaikkan investasi sebesar Rp 1.81537. Sedangkan dari $R$ square $\left(R^{2}\right)$ investasi ke pembiayaan adalah 0,600002 . Hal ini berarti $60 \%$ investasi dapat dijelaskan oleh variabel pembiayaan dengan time lag 7 tahun. Sedangkan sisanya $(100 \%-60 \%=40 \%)$ dijelaskan oleh sebab-sebab yang lain. Sebaliknya hubungan antara pembiayaan dengan investasi, diketahui bahwa $R^{2}$ ( $R$ square) pembiayaan ke investasi adalah 
0,582671. Hal ini berarti $58 \%$ pembiayaan dapat dijelaskan oleh variabel investasi dengan time lag 7 tahun. Sedangkan sisanya $(100 \%-58 \%=$ 42\%) dijelaskan oleh oleh sebab-sebab yang lain. Berdasarkan uji T investasi ke pembiayaan 11.310293, dan pembiayaan ke investasi 12.227962 dengan tingkat signifikan $1 \%$. Jika $T_{\text {stat }}>T_{\text {tabel, }}$, tolak $H_{0}$, terima $\mathrm{H}_{\mathrm{a}}$ ada pengaruh yang nyata dari variabel investasi dengan pembiayaan secara individu demikian juga sebaliknya ada pengaruh yang nyata antara variabel pembiayaan dengan investasi secara individu.

Tabel 2. Hasil perhitungan Uji Greger

untuk kausalitas menggunakan pooling data langkah dua

\begin{tabular}{|l|c|c|c|c|}
\hline Persamaan GLS & \multicolumn{1}{|c|}{$\beta \mathrm{i}$} & \multicolumn{1}{c|}{ Se $\beta \mathrm{i}$} & \multicolumn{1}{c|}{$\mathrm{T}$} & $\mathrm{R}^{2}$ \\
\hline $\mathrm{INV}=\sum_{\mathrm{i}-7}^{\mathrm{m}} \mathrm{INV}_{\mathrm{t}-7}+\mathrm{FIN}$ & 1.81537 & 0.160506 & 11.310293 & 0.600002 \\
$\mathrm{FIN}=\sum_{\mathrm{i}-7}^{\mathrm{m}} \mathrm{FIN}_{\mathrm{t}-7}+\mathrm{INV}$ & 1.175364 & 0.096121 & 12.227962 & 0.582671 \\
\hline FINLDT $=\sum_{\mathrm{i}-7}^{\mathrm{m}} \mathrm{LDT}_{\mathrm{t}-7}+\mathrm{DIV}$ & 3.870954 & 1.086297 & 3.563439 & 0.472219 \\
$\mathrm{DIV}=\sum_{\mathrm{i}-7}^{\mathrm{m}} \mathrm{DIV}_{\mathrm{t}-7}+\mathrm{FINLDT}$ & 0.773491 & 0.103014 & 7.508600 & 0.397348 \\
\hline $\mathrm{INV}=\sum_{\mathrm{i}-7}^{\mathrm{m}} \mathrm{INV}_{\mathrm{t}-7}+\mathrm{DIV}$ & 2.216871 & 0.676253 & 3.278168 & 0.477255 \\
DIV $=\sum_{\mathrm{i}-7}^{\mathrm{m}} \mathrm{DIV}_{\mathrm{t}-7}+\mathrm{INV}$ & 0.699774 & 0.110487 & 6.333541 & 0.361143 \\
\hline
\end{tabular}

Sumber : Lampiran 4 s. d. 12

T tabel $1 \%=2.66 ; 5 \%=2.00 ; 10 \%=1.67$

Pada kolom 2 hubungan antara pembiayaaan dari laba ditahan dengan dividen, dimana $\beta_{i}$ (koefisien regresi) pembiayaan dari laba ditahan 0.773491 yang menyatakan bahwa setiap penambahan (karena tanda + ) Rp 1 akan menaikkan dividen sebesar Rp 0.773491. Begitu juga dengan $\beta_{i}$ (koefisien regresi) dividen 3.870954, yang menyatakan bahwa setiap penambahan Rp 1 akan menaikkan dividen sebesar Rp 3.870954. Sedangkan dari $R$ square $\left(R^{2}\right)$ pembiayaan dari laba ditahan adalah 0,472219 . Hal ini berarti $47 \%$ pembiayaan dari laba ditahan dapat dijelaskan oleh variabel dividen dengan time lag 7 tahun. Sedangkan sisanya $(100 \%-47 \%=53 \%)$ dijelaskan oleh sebab-sebab yang lain. Sebaliknya hubungan antara pembiayaan dengan investasi, diketahui bahwa $R^{2}(R$ 
square) dividen ke pembiayaan adalah 0,397348. Hal ini berarti $40 \%$ dividen dapat dijelaskan oleh variabel pembiayaan dari laba ditahan dengan time lag 7 tahun. Sedangkan sisanya $(100 \%$ - 40\% = 60\%) dijelaskan oleh oleh sebab-sebab yang lain. Berdasarkan uji T pembiayaan dari laba ditahan ke dividen 3.563439 , dan dividen ke pembiayaan dari laba ditahan 7.508600 dengan tingkat signifikan 1\%. Jika $\mathrm{T}_{\text {stat }}>\mathrm{T}_{\text {tabel, }}$, tolak $\mathrm{H}_{0}$, terima $\mathrm{H}_{\mathrm{a}}$ ada pengaruh yang nyata dari varibel pembiayaan dari laba ditahan dengan dividen secara individu demikian juga sebaliknya ada pengaruh yang nyata antara variabel dividen dengan pembiayaan dari laba ditahan secara individu.

Persamaan GLS pada kolom 3 hubungan antara investasi dengan dividen, dimana $\beta_{i}$ (koefisien regresi) investasi 0.699774 yang menyatakan bahwa setiap penambahan (karena tanda +) Rp 1 akan menaikkan dividen sebesar Rp 0.699774. Begitu juga dengan $\beta_{i}$ (koefisien regresi) dividen 2.216871, yang menyatakan bahwa setiap penambahan Rp 1 akan menaikkan investasi sebesar Rp 2.216871. Sedangkan dari R square $\left(R^{2}\right)$ investasi ke dividen adalah 0,477255. Hal ini berarti 47,7\% investasi dapat dijelaskan oleh variabel dividen dengan time lag 7 tahun. Sedangkan sisanya $(100 \%-47,7 \%=52,3 \%)$ dijelaskan oleh sebab-sebab yang lain. Sebaliknya hubungan antara dividen dengan investasi, diketahui bahwa $\mathrm{R}^{2}$ (R square) dividen ke investasi adalah 0,361143. Hal ini berarti 36\% pembiayaan dapat dijelaskan oleh variabel investasi dengan time lag 7 tahun. Sedangkan sisanya $(100 \%$ - 36\% = 64\%) dijelaskan oleh oleh sebab-sebab yang lain. Berdasarkan uji T investasi ke dividen 3.278168, dan dividen ke investasi 6.333541 dengan tingkat signifikan $1 \%$. Jika $T_{\text {stat }}>T_{\text {tabel, }}$ tolak $H_{0}$, terima $\mathrm{H}_{\mathrm{a}}$ ada pengaruh yang nyata dari variabel investasi dengan dividen secara individu demikian juga sebaliknya ada pengaruh yang nyata antara variabel dividen dengan investasi secara individu.

\section{Uji Vector Autoregressive (VAR)}

Uji VAR digunakan sebagai pelengkap dari Uji Greger yaitu menentukan signifikansi dari persamaan VAR endogen sebagai variabel independen ke variavel dependen. Hal ini dapat dilihat pada tabel 3.

Dari tabel 3 kolom 1 Persamaan VAR pada kolom 1 yaitu hubungan antara investasi dengan pembiayaaan, dimana $\beta_{i}$ (koefisien regresi) investasi 1.488513 yang menyatakan bahwa setiap penambahan (karena tanda +) Rp 1 akan menaikkan pembiayaan sebesar Rp 1.488513. Begitu juga dengan $\beta_{i}$ (koefisien regresi) pembiayaan 1.592929, yang menyatakan bahwa setiap penambahan Rp 1 akan menaikkan investasi sebesar Rp 1.592929. Sedangkan dari $R$ square $\left(R^{2}\right)$ investasi ke pembiayaan adalah 0,523926 . Hal ini berarti $52 \%$ investasi dapat dijelaskan oleh variabel pem- 
biayaan dengan time lag 7 tahun. Sedangkan sisanya (100\% - 52\% = 38\%) dijelaskan oleh sebab-sebab yang lain. Sebaliknya hubungan antara pembiayaan dengan investasi, diketahui bahwa $R^{2}$ ( $R$ square) pembiayaan ke investasi adalah 0,705789 . Hal ini berarti $70 \%$ pembiayaan dapat dijelaskan oleh variabel investasi dengan time lag 7 tahun. Sedangkan sisanya $(100 \%-70 \%=30 \%)$ dijelaskan oleh oleh sebab-sebab yang lain. Berdasarkan uji $\mathrm{F}$ investasi ke pembiayaan 4.501269, dan pembiayaan ke investasi 7.516620 dengan tingkat signifikan $1 \%$. Jika $\mathrm{F}_{\text {stat }}>\mathrm{F}_{\text {tabel, }}$ tolak $\mathrm{H}_{0}$, terima $\mathrm{H}_{a}$, signifikan ada pengaruh yang nyata dari variabel investasi dengan pembiayaan secara keseluruhan demikian juga sebaliknya ada pengaruh yang nyata dari variabel pembiayaan dengan investasi secara keseluruhan. Berdasarkan uji T investasi ke pembiayaan 14.59809, dan pembiayaan ke investasi 7.822175 dengan tingkat signifikan $1 \%$. Jika $T_{\text {stat }}>$ $T_{\text {tabel, }}$ tolak $H_{0}$, terima $H_{a}$, yang artinya ada pengaruh yang nyata dari variabel investasi dengan pembiayaan secara individu demikian juga sebaliknya ada pengaruh yang nyata antara pembiayaan dengan investasi secara individu.

Tabel 3. Hasil perhitungan Vektor Autoregressive (VAR) menggunakan pooling data

\begin{tabular}{|c|c|c|c|c|c|}
\hline Persamaan VAR & $\beta_{\mathrm{i}}$ & Se $\beta_{\mathrm{i}}$ & $\mathrm{T}$ & $\mathbf{F}$ & $\mathbf{R}^{2}$ \\
\hline$f(\mathrm{INV})=\sum_{i=7}^{m} \mathrm{INV}_{\mathrm{t}-7}+\mathrm{FIN}+\sum_{i=7}^{m} \mathrm{FIN}_{\mathrm{t}-7}$ & 1.592929 & 0.109119 & 14.59809 & 4.501269 & 0.523926 \\
$f(\mathrm{FIN})=\sum_{i=7}^{m} \mathrm{FIN}_{\mathrm{t}-7}+\mathrm{INV}+\sum_{i=7}^{m} \mathrm{INV}_{\mathrm{t}-7}$ & 1.488513 & 0.190294 & 7.822175 & 7.516620 & 0.705789 \\
\hline$f(\mathrm{FIN} \mathrm{LDT})=\sum_{i=7}^{m} \mathrm{LDT}_{\mathrm{t}-7}+\mathrm{DIV}+\sum_{i=7}^{m} \mathrm{DIV}_{\mathrm{t}-7}$ & 6.065738 & 1.070180 & 5.667960 & 5.317193 & 0.629214 \\
$f(\mathrm{DIV})=\sum_{i=7}^{m} \mathrm{DIV}_{\mathrm{t}-7}+\mathrm{FIN} \mathrm{LDT}+\sum_{i=7}^{m} \mathrm{LDT}_{\mathrm{t}-7}$ & 0.628949 & 0.117384 & 5.358047 & 2.841592 & 0.475586 \\
\hline$f(\mathrm{INV})=\sum_{i=7}^{m} \mathrm{INV}_{\mathrm{t}-7}+\mathrm{DIV}+\sum_{i=7}^{m} \mathrm{DIV}_{\mathrm{t}-7}$ & 1.954569 & 0.711853 & 2.745748 & 2.691480 & 0.462071 \\
$f(\mathrm{DIV})=\sum_{i=7}^{m} \mathrm{DIV}_{\mathrm{t}-7}+\mathrm{INV}+\sum_{i=7}^{m} \mathrm{INV}_{\mathrm{t}-7}$ & 0.852731 & 0.129348 & 6.592533 & 3.284944 & 0.511811 \\
\hline
\end{tabular}

Keterangan:

F-tabel $=(6.63) ; 1 \%=3.12 ; 5 \%=2.25 ; 10 \%=1.87$

T tabel $1 \%=2.66 ; 5 \%=2.00 ; 10 \%=1.67$

Pada kolom 2 yaitu hubungan antara pembiayaaan dari laba ditahan dengan dividen, dimana $\beta_{i}$ (koefisien regresi) pembiayaan dari laba ditahan 0.628949 yang menyatakan bahwa setiap penambahan (karena tanda +) Rp 1 akan menaikkan dividen sebesar Rp 0.628949. Begitu juga 
dengan $\beta_{i}$ (koefisien regresi) dividen 6.065738 , yang menyatakan bahwa setiap penambahan Rp 1 akan menaikkan pembiayaan dari laba ditahan sebesar Rp 3.567160. Sedangkan dari R square (R2) pembiayaan dari laba ditahan adalah 0,629214. Hal ini berarti $63 \%$ pembiayaan dari laba ditahan dapat dijelaskan oleh variabel dividen dengan time lag 7 tahun. Sedangkan sisanya $(100 \%-63 \%=37 \%)$ dijelaskan oleh sebab-sebab yang lain. Sebaliknya hubungan antara dividen dengan pembiayaan dari laba ditahan, diketahui bahwa R2 (R square) dividen ke pembiayaan laba ditahan adalah 0,475586 . Hal ini berarti $47 \%$ dividen dapat dijelaskan oleh variabel pembiayaan dari laba ditahan dengan time lag 7 tahun. Sedangkan sisanya $(100 \%-47 \%=53 \%)$ dijelaskan oleh oleh sebab-sebab yang lain. Berdasarkan uji T pembiayaan dari laba ditahan ke dividen 5.667960, dan dividen ke pembiayaan dari laba ditahan 5.358047 dengan tingkat signifikan 1\%. Jika Tstat > Ttabel, tolak $\mathrm{Ho}$, terima $\mathrm{Ha}$ ada pengaruh yang nyata dari varibel pembiayaan dari laba ditahan dengan dividen secara individu demikian juga sebaliknya ada pengaruh yang nyata antara variabel dividen dengan pembiayaan dari laba ditahan secara individu. Hasil uji $\mathrm{F}$ pembiayaan dari laba ditahan ke dividen 5.317193 , dan dividen ke pembiayaan dari laba ditahan 2.841592 dengan tingkat signifikan 1\%. Jika Fstat > Ftabel, tolak $\mathrm{Ho}$, terima $\mathrm{Ha}$, signifikan ada pengaruh yang nyata dari variabel pembiayaan dari laba ditahan dengan dividen secara keseluruhan demikian juga sebaliknya ada pengaruh yang nyata dari variabel dividen dengan pembiayaan dari laba ditahan secara keseluruhan.

Persamaan VAR pada kolom 3 tabel 3 yaitu hubungan antara investasi dengan dividen, dimana $\beta_{i}$ (koefisien regresi) investasi 0.852731 yang menyatakan bahwa setiap penambahan (karena tanda +) Rp. 1 akan menaikkan dividen sebesar Rp 0.852731. Begitu juga dengan $\beta_{i}$ (koefisien regresi) dividen 1.954569 , yang menyatakan bahwa setiap penambahan Rp 1 akan menaikkan investasi sebesar Rp. 1.954569. Sedangkan dari R square (R2) investasi ke dividen adalah 0,462071. Hal ini berarti $46 \%$ investasi dapat dijelaskan oleh variabel pembiayaan dengan time lag 7 tahun. Sedangkan sisanya $(100 \%$ - 46\% $=54 \%)$ dijelaskan oleh sebab-sebab yang lain. Sebaliknya hubungan antara dividen dengan investasi, diketahui bahwa R2 (R square) dividen ke investasi adalah 0,511811. Hal ini berarti $50 \%$ dividen dapat dijelaskan oleh variabel investasi dengan time lag 7 tahun. Sedangkan sisanya $(100 \%-50 \%=50 \%)$ dijelaskan oleh oleh sebab-sebab yang lain. Berdasarkan uji $F$ investasi ke dividen 2.691480 , dan dividen ke investasi 3.284944 dengan tingkat signifikan 1\% untuk investasi ke dividen dan 5\% untuk dividen ke investasi. Jika Fstat > Ftabel, tolak $\mathrm{Ho}$, terima $\mathrm{Ha}$, signifikan ada pengaruh yang nyata dari variabel in- 
vestasi dengan dividen secara keseluruhan demikian juga sebaliknya ada pengaruh yang nyata dari variabel dividen dengan investasi secara keseluruhan. Berdasarkan uji T investasi ke dividen 2.745748 dengan tingkat signifikan 5\%, dan dividen ke investasi 6.592533 dengan tingkat signifikan $1 \%$. Jika Tstat > Ttabel, tolak $\mathrm{Ho}$, terima $\mathrm{Ha}$, yang artinya ada pengaruh yang nyata dari variabel investasi dengan dividen secara individu demikian juga sebaliknya ada pengaruh yang nyata antara variabel dividen dengan investasi secara individu.

Berdasarkan koofesien determinan $\mathrm{R}$ square untuk investasi , pembiayaan dan pembiayaan dari laba ditahan diatas rata-rata $50 \%$. Sedangkan untuk dividen kurang dari 50\%. Rendahnya tingkat kepercayaan terhadap hasil penelitian menurut Sudjana (1982) diakibatkan adanya sejumlah faktor penyebab yang relevan yang tidak tercakup dalam penelitian.

\section{Uji Hipotesis}

Dari hasil ke dua uji Granger maupun Vektor Autoregressive (VAR) dapat diambil kesimpulan apakah ada hubungan kausalitas dua arah atau satu arah maka digunakan model regresi linier yang akan menghasilkan empat kemungkinan mengenai nilai koefisien-koefisien masing-masing:

1. Jika $\sum_{i=1}^{m} \alpha_{i} \neq 0$ dan $\sum_{\mathrm{i}=1}^{\mathrm{m}} \beta_{\mathrm{i}} \neq 0$., maka terdapat kausalitas dua arah antara $\mathrm{Y}$ dan $\mathrm{X}$ dalam hal ini antara INV dan FIN, FIN LDT dan DIV, INV dan DIV

2. Jika $\sum_{i=1}^{m} \alpha_{i} \neq 0$ dan $\sum_{\mathrm{i}=1}^{\mathrm{m}} \beta_{\mathrm{i}}=0$ maka terdapat kausalitas satu arah antara dari $Y$ ke $X$ dalam hal ini antara INV ke FIN , FIN LDT ke DIV dan INV ke DIV

3. Jika $\sum_{i=1}^{m} \alpha_{i}=0$ dan $\sum_{\mathrm{i}=1}^{\mathrm{m}} \beta_{\mathrm{i}} \neq 0$ maka terdapat kausalitas satu arah dari X ke $Y$ dalam hal ini antara INV ke FIN , FIN LDT ke DIV dan INV ke DIV

4. Jika $\sum_{i=1}^{m} \alpha_{i}=0$ dan $\sum_{i=1}^{\mathrm{m}} \beta_{i}=0$, maka INV, FIN LDT, dan DIV bebas antara satu dengan lainnya.

Dari keempat kemungkinan diatas maka diperoleh hasil sebagai berikut:

- Hipotesis kerja kesatu $\left(\mathrm{H}_{1}\right)$ INV ke FIN

Hubungan dua arah positif ditunjukkan pengaruhnya antara investasi (INV) dengan pembiayaan (FIN) (dari laba ditahan, penerbitan saham baru dan utang jangka panjang) sebesar 1.175364 yang artinya jika investasi naik sebesar 1 rupiah maka akan menaikkan pembiayaan 
sebesar 1175.364 rupiah. Demikian juga dengan pengaruh pembiayaan terhadap investasi sebesar 1.815370 yang artinya jika pembiayaan naik sebesar 1 rupiah maka akan menaikkan investasi sebesar 1815.370 (Uji Granger tabel 2 dari koefisien regresi $\beta_{i}$ ). Sedangkan dari Uji Vektor Autoregressive (VAR) ada hubungan dua arah yang positif antara investasi dengan pembiayaan sebesar 1.488513 yang artinya jika investasi naik sebesar 1 rupiah maka akan menaikkan pembiayaan sebesar 1.488 .513 rupiah. Demikian juga dengan pengaruh pembiayaan terhadap investasi sebesar 1.592929 yang artinya jika pembiayaan naik sebesar 1 rupiah maka akan menaikkan investasi sebesar 1.592 .929 (tabel 3 dari koefisien regresi $\beta_{i}$ )

Kesimpulan dari hasil hipotesis kerja kesatu Ho1= 0 ditolak dan Ha1: $\beta_{1} \neq 0$, diterima artinya keputusan investasi berpengaruh terhadap keputusan pembiayaan dari laba ditahan, hutang jangka panjang, dan modal saham beredar dengan arah positif atau sebaliknya keputusan pembiayaan dari laba ditahan, hutang jangka panjang, dan modal saham beredar berpengaruh terhadap keputusan investasi dengan arah positif.

- Hipotesis kerja kedua $\left(\mathrm{H}_{2}\right)$ FIN LDT ke INV

Berdasarkan Uji T dan Uji F ada pengaruh yang nyata antara variabel pembiayaan dari laba ditahan dengan dividen baik secara individu maupun secara keseluruhan. Tetapi berdasarkan uji kausalitas empat kemungkinan, hubungan antara pembiayaan dari laba ditahan dengan dividen cuma satu arah yaitu dari $Y$ ke $X$ dalam hal ini ada hubungan searah positif antara pembiayaan dari laba ditahan dengan dividen.

Kesimpulan hasil hipotesis kerja kedua $\mathrm{Ho} 2=0$ ditolak dan Ha2: $\beta_{2} \neq 0$, diterima artinya keputusan pembiayaan dari laba ditahan berpengaruh terhadap keputusan dividen dengan satu arah positif. Sebaliknya keputusan dividen tidak berpengaruh terhadap pembiayaan dari laba ditahan. Artinya naiknya pembiayaan dari laba ditahan sebesar 0.773491 tidak akan menaikkan dividen sebesar 0.773491(berdasarkan uji granger tabel 2) sedangkan berdasarkan uji VAR (tabel 3) naiknya pembiayaan dari laba ditahan sebesar 0.628949 tidak akan menaikkan dividen sebesar 0.628949. Dengan kata lain naiknya pembiayaan dari laba ditahan sebesar 1 rupiah maka tidak akan menaikkan dividen.

Temuan dalam penelitian ini bertentangan dengan temuan penelitian terdahulu yang dilakukan oleh Made Sudarman (1997) yang menyatakan bahwa adanya hubungan kausalitas dua arah antara positif antara pembiayaan dari laba ditahan dengan investasi. Hal ini 
disebabkan karena kondisi populasi dan sampel obyek penelitian yang berbeda dengan penelitian terdahulu, dimana populasi penelitian terdahulu merupakan perusahaan manufactur yang pasarnya heterogen, selain itu perusahaan manufactur memiliki aktiva tetap berwujud sebagai unsur investasi yang dominan dari total aktiva perusahaan sedangkan pada perusahaan asuransi pasarnya relatif homogen dan merupakan perusahaan yang bergerak dibidang jasa .

Keputusan dividen tidak dipengaruhi oleh variabel pembiayaan yang berasal dari laba ditahan karena jumlah pembayaran dividen yang dilakukan selama ini sangat rendah jika dibandingkan penambahan dari penerbitan saham dan utang jangka panjang. Pemegang saham lebih mengutamakan pada peningkatan nilai perusahaan asuransi dan kurang berorientasi terhadap besar kecilnya dividen yang dibagikan, karena pemegang sahamnya berasal dari grup atau patner kerjasama.

- Hipotesis kerja ketiga $\left(\mathrm{H}_{3}\right)$ INV ke DIV

Berdasarkan Uji $\mathrm{T}$ dan Uji $\mathrm{F}$ ada pengaruh yang nyata antara variabel investasi dengan dividen baik secara individu maupun secara keseluruhan. Tetapi berdasarkan uji kausalitas empat kemungkinan, hubungan antara investasi dengan dividen cuma satu arah yaitu dari $Y$ ke $X$ dalam hal ini ada hubungan searah positif antara investasi dengan dividen.

Kesimpulan hasil hipotesis kerja kedua $\mathrm{Ho}=0$ ditolak dan Ha3: $\beta_{3} \neq 0$, diterima artinya keputusan investasi berpengaruh terhadap keputusan dividen dengan satu arah positif. Artinya naiknya investasi sebesar 0.699774 tidak akan menaikkan dividen sebesar 0.69974 (berdasarkan uji granger tabel 2) sedangkan berdasarkan uji VAR (tabel 3) naiknya investasi sebesar 0.852731 tidak akan menaikkan dividen sebesar 0.852731. Dengan kata lain naiknya investasi sebesar 1 rupiah maka tidak akan menaikkan dividen. Sebaliknya keputusan dividen tidak berpengaruh terhadap keputusan investasi.

Temuan dalam penelitian ini bertentangan dengan temuan-temuan penelitian terdahulu yang dilakukan oleh Made Sudarma yang menyatakan bahwa adanya hubungan kausalitas dua arah antara positif antara investasi dengan dividen. Hal ini disebabkan karena kondisi populasi dan sampel obyek penelitian yang berbeda dengan penelitian terdahulu, dimana populasi penelitian terdahulu merupakan perusahaan manufactur yang pasarnya heterogen selain itu perusahaan manufactur memiliki aktiva tetap berwujud sebagai unsur investasi yang dominan dari total aktiva perusahaan sedangkan pada perusahaan asuransi pasarnya relatif homogen dan merupakan perusahaan yang bergerak dibidang jasa. 


\section{PENUTUP}

Hasil penelitian terhadap kausalitas antara ketiga variabel keputusan menunjukkan bahwa terdapat hubungan antara ketiga keputusan tersebut meskipun tidak secara keseluruhan (hubungan dua arah antara ketiga keputusan tidak secara menyeluruh ada) dan sifatnya lemah. Keadaan ini menunjukkan bahwa perusahaan asuransi yang ada di Bursa Efek Jakarta berada pada teori pertama Miller dan Modigliani (1958) yang menyatakan bahwa kebijakan dividen perusahaan tidak ada pengaruhnya terhadap nilai perusahaan maupun biaya modal seperti dikemukakan olehSutrisno (1996).

Dari hasil uji hipotesis kesatu, diterima secara signifikan adanya hubungan kausalitas dua arah yang positif antara investasi dengan pembiayaan. Keputusan investasi dipengaruhi oleh pembiayaan yang berasal dari laba yang ditahan, pembiayaan yang berasal dari saham baru dan pembiayaan yang berasal dari utang jangka panjang. Temuan ini memberikan implikasi bahwa naiknya investasi sebesar 1 rupiah akan menyebabkan naiknya pembiayaan demikian juga sebaliknya jika pembiayaan naik sebesar 1 rupiah maka akan menaikkan investasi.

Adanya temuan yang berbeda dengan penelitian Made Sudarman dalam penelitiannya pada perusahaan manufactur adanya hubungan kausalitas dua arah positif antara keputusan pembiayaan dari laba ditahan dengan dividen dan investasi dengan dividen. Hasil penelitian ini menunjukkan Hipotesis kerja kedua dan ketiga bertentangan dengan hasil penelitian. Dimana berdasarkan uji $\mathrm{T}$ dan uji $\mathrm{F}$ diperoleh hasil bahwa adanya hubungan antara pembiayaan dari laba ditahan dengan dividen dan investasi dengan dividen baik secara individu maupun secara keseluruhan, tetapi berdasarkan uji kausalitas empat kemungkinan ada hubungan antara pembiayaan dari laba ditahan dengan dividen dan investasi dengan dividen tetapi hanya searah ( $\mathrm{Y}$ ke $\mathrm{X}$ ) bukan dua arah.

Keputusan dividen tidak dipengaruhi oleh variabel pembiayaan yang berasal dari laba ditahan karena jumlah pembayaran dividen yang dilakukan selama ini sangat rendah jika dibandingkan penambahan pembiayaan yang diperoleh dari kedua sumber pembiayaan yang berasal dari penerbitan saham dan utang jangka panjang. Pemegang saham lebih mengutamakan pada peningkatan nilai perusahaan asuransi dan kurang berorientasi terhadap dividen karena pemegang sahamnya berasal dari grup atau patner kerja sama.

Kesimpulan dari temuan hipotesis kedua dan ketiga megindikasikan bahwa keputusan dividen tidak berpengaruh terhadap keputusan manajemen maupun pihak ketiga dalam investasi dan pembiayaan yang 
berasal dari laba ditahan, penambahan saham baru dan utang jangka panjang. Ketidak absolutan hasil yang diperoleh ini disebabkan oleh kondisi populasi dan sampel obyek penelitian yang berbeda dengan penelitian terdahulu, dimana populasi penelitian terdahulu merupakan perusahaan manufactur yang pasarnya relatif heterogen selain itu perusahaan manufactur memiliki aktiva tetap berwujud sebagai unsur investasi yang dominan dari total aktiva perusahaan sedangkan pada perusahaan asuransi pasarnya relatif homogen dan merupakan perusahaan yang bergerak dibidang jasa.

\section{DAFTAR PUSTAKA}

Arief, Sritua., Metodologi Penelitian Ekonomi, Penerbit Universitas Indonesia, Jakarta, 1993.

Brigham, Eugene, Intermediate of Financial Management, Sixth Edition, Harcourt Brace College Publishers, 1999.

Gurajati, Damodar., Ekonometrika Dasar, Penerbit Erlangga, Jakarta, 1998.

Halim, Abdul., Analisis Investasi, Edisi Pertama, Penerbit Salemba Empat, Jakarta, 2003.

Harianto, Farid dan Sudomo Siswanto, Perangkat dan Tehnik Analisis Investasi di Pasar Modal Indonesia, Penerbit Bursa Efek Jakarta, 1998.

Husnan, Suad., Manajemen Keuangan, Edisi kelima, Penerbit BPFE, Yogyakarta, 1992.

Jones, P Charles Investments, Analysis and Management, Seventh Edition, John Willey and Son, 2000.

Kolari - Rose, Financial Institutios Understanding and Managing Financial Services, Fifth Edition, 1995.

L Jacob, Nancy and Pettit, R Richad, Investment: Management Decisions and value, Toppan Co Ltd, and Richard D Irwin, Printed in Singapore, 1990.

Litner, John, Dividend, Earning, Leverage, Stock Prices, andthe supply of Capital to corporations, Review of Economics and Statistitc, Agustus 1996.

Myron J Gordon, Optimal Investment and Financing Policy, Journal of Finance, Mei 1963. 
Mukherjee, K. Tarun and Mougoue Mboja, An Investigation Into The Causality Among Firms, Dividend, Investment and Financing Decisions, Journal of Financial Research, 1994

Santoso, Singgih., SPSS Versi 10, Mengolah Data Statistik Secara Profesional, Penerbit PT Elex Media Komputindo, Jakarta, 2001.

Sudarman, Made., Analisis Kausalitas Kebijakan Dividen, Investasi dan Pembiayaan Pada Perusahaan Manufaktur di Bursa Efek Surabaya, Brawijaya, 1997.

Sudjana, Metode Statistika, PT. Tarsito Bandung, 1982

Sutrisno, Manajemen Keuangan (Teori, Konsep dan Aplikasi), Edisi Pertama, Cetakan Kedua, Penerbit EKONISIA, Fakultas Ekonomi UII, Yogyakarta, 2001.

Umar, Husein,. Research Methods in Finance and Bangking, Penerbit PT Gramedia Pustaka Utama, Jakarta, 2000. 
Lampiran.

Variabel Investasi (INV), Pembiayaan (FIND), Pembiayaan dari Laba Ditahan (FIND LDT), dan Dividen (DIV)

\begin{tabular}{|c|c|c|c|c|}
\hline NO & $\begin{array}{l}\text { INVESTASI } \\
\text { (INV) }\end{array}$ & $\begin{array}{c}\text { Sumber Dana } \\
\text { (FIND) }\end{array}$ & $\begin{array}{l}\text { Sumber Dana Laba } \\
\text { Ditahan (FIND LTD) }\end{array}$ & $\begin{array}{l}\text { DIVIDEN } \\
\text { (DIV) }\end{array}$ \\
\hline 1 & 13.419 .000 .000 & 12.954 .300 .000 & 16.317 .000 .000 & 5.498 .000 .000 \\
\hline 2 & 16.494 .500 .000 & 15.672 .300 .000 & 21.927 .000 .000 & 0 \\
\hline 3 & 9.873 .000 .000 & 12.418 .300 .000 & 10.643 .000 .000 & 0 \\
\hline 4 & 8.384 .000 .000 & 18.315 .000 .000 & 10.037 .000 .000 & 1.196 .000 .000 \\
\hline 5 & 24.118 .000 .000 & 37.419 .000 .000 & 50.053 .000 .000 & 4.828 .000 .000 \\
\hline 6 & 31.512 .000 .000 & 41.330 .700 .000 & 26.559 .000 .000 & 5.623 .000 .000 \\
\hline 7 & 32.662 .000 .000 & 48.318 .000 .000 & 28.896 .000 .000 & 3.622 .000 .000 \\
\hline 8 & 3.146 .500 .000 & 18.380 .300 .000 & 23.561 .000 .000 & 2.503 .000 .000 \\
\hline 9 & 3.502 .000 .000 & 22.019 .700 .000 & 33.312 .000 .000 & 0 \\
\hline 10 & 2.509 .500 .000 & 24.227 .700 .000 & 11.957 .000 .000 & 3.828 .000 .000 \\
\hline 11 & 2.400 .500 .000 & 28.394 .000 .000 & 23.943 .000 .000 & 3.846 .000 .000 \\
\hline 12 & 3.703 .000 .000 & 32.298 .000 .000 & 35.763 .000 .000 & 2.003 .000 .000 \\
\hline 13 & 29.073 .000 .000 & 33.368 .700 .000 & 31.727 .000 .000 & 6.708 .000 .000 \\
\hline 14 & 24.192 .500 .000 & 39.938 .300 .000 & 40.586 .000 .000 & 2.637 .000 .000 \\
\hline 15 & 8.496 .000 .000 & 5.950 .000 .000 & 6.750 .000 .000 & 1.008 .000 .000 \\
\hline 16 & 7.497 .000 .000 & 6.951 .700 .000 & 9.801 .000 .000 & 0 \\
\hline 17 & 10.106 .000 .000 & 7.300 .300 .000 & 11.904 .000 .000 & 180.000 .000 \\
\hline 18 & 4.395 .500 .000 & 7.207 .700 .000 & 12.375 .000 .000 & 0 \\
\hline 19 & 977.000 .000 & 7.488 .700 .000 & 12.378 .000 .000 & 449.000 .000$. \\
\hline 20 & 5.218 .000 .000 & 8.007 .700 .000 & 12.518 .000 .000 & 842.000 .000 \\
\hline 21 & 5.779 .000 .000 & 8.846 .000 .000 & 13.429 .000 .000 & 1.800 .000 .000 \\
\hline 22 & 28.428 .450 .000 & 49.755 .700 .000 & 33.975 .000 .000 & 1.008 .000 .000 \\
\hline 23 & 88.987 .800 .000 & 173.511 .300 .000 & 126.093 .000 .000 & 1.542 .000 .000 \\
\hline 24 & 92.299 .450 .000 & 809.150 .000 .000 & $(308.036 .000)$ & 0 \\
\hline 25 & 54.020 .200 .000 & 375.448 .300 .000 & $(1.679 .863 .000)$ & 0 \\
\hline 26 & 10.060 .500 .000 & 441.698 .300 .000 & $((1.510 .190 .000)$ & 0 \\
\hline 27 & 15.266 .000 .000 & 493.578 .700 .000 & $(1.355 .765 .000)$ & 0 \\
\hline 28 & 11.928 .500 .000 & 519.183 .000 .000 & $(1.275 .000 .000)$ & 0 \\
\hline 29 & 4.042 .500 .000 & 17.772 .300 .000 & 8.996 .000 .000 & 0 \\
\hline 30 & 4.427 .000 .000 & 18.866 .300 .000 & 12.554 .000 .000 & 738.000 .000 \\
\hline 31 & 6.586 .000 .000 & 18.244 .000 .000 & 12.127 .000 .000 & 505.000 .000 \\
\hline 32 & 4.303 .000 .000 & 21.985 .000 .000 & 17.766 .000 .000 & 0 \\
\hline 33 & 6.709 .500 .000 & 22.238 .700 .000 & 23.977 .000 .000 & 671.000 .000 \\
\hline 34 & 27.984 .000 .000 & 27.436 .300 .000 & 28.040 .000 .000 & 782.000 .000 \\
\hline
\end{tabular}




\begin{tabular}{|c|c|c|c|c|}
\hline 35 & 35.523 .500 .000 & 33.074 .000 .000 & 38.580 .000 .000 & 3.194 .000 .000 \\
\hline 36 & 4.631 .000 .000 & 12.386 .700 .000 & 3.278 .000 .000 & 0 \\
\hline 37 & 4.569 .500 .000 & 14.029 .300 .000 & 4.385 .000 .000 & 1.786 .000 .000 \\
\hline 38 & 4.428 .000 .000 & 15.422 .700 .000 & 7.918 .000 .000 & 3.711 .000 .000 \\
\hline 39 & 4.226 .500 .000 & 18.934 .300 .000 & 7.546 .000 .000 & 2.517 .000 .000 \\
\hline 40 & 4.165 .000 .000 & 18.026 .000 .000 & 8.611 .000 .000 & 2.306 .000 .000 \\
\hline 41 & 5.372 .500 .000 & 20.207 .300 .000 & 6.982 .000 .000 & 718.000 .000 \\
\hline 42 & 16.641 .000 .000 & 24.877 .300 .000 & 10.073 .000 .000 & 2.276 .000 .000 \\
\hline 43 & 7.186 .000 .000 & 12.249 .300 .000 & 4.751 .000 .000 & 0 \\
\hline 44 & 4.285 .500 .000 & 27.573 .000 .000 & 10.797 .000 .000 & 983.000 .000 \\
\hline 45 & 5.295 .000 .000 & 45.687 .300 .000 & 20.515 .000 .000 & 1.185 .000 .000 \\
\hline 46 & 5.505 .000 .000 & 40.887 .300 .000 & 20.881 .000 .000 & 344.000 .000 \\
\hline 47 & 6.368 .000 .000 & 35.247 .300 .000 & 18.365 .000 .000 & 0 \\
\hline 48 & 11.252 .500 .000 & 29.502 .700 .000 & 12.840 .000 .000 & 0 \\
\hline 49 & 11.921 .000 .000 & 31.411 .700 .000 & 13.185 .000 .000 & 0 \\
\hline 50 & 72.757 .500 .000 & 48.561 .000 .000 & 20.738 .000 .000 & 902.000 .000 \\
\hline 51 & 79.538 .500 .000 & 53.285 .700 .000 & 33.926 .000 .000 & 0 \\
\hline 52 & 244.539 .000 & 250.939 .700 & 120.492 .000 & 0 \\
\hline 53 & 314.890 .000 & 319.222 .000 & 132.069 .000 & 0 \\
\hline 54 & 755.477 .000 & 507.260 .700 & 896.162 .000 & 0 \\
\hline 55 & 662.720 .000 & 428.512 .700 & 221.496 .000 & 0 \\
\hline 56 & 683.012 .000 & 435.988 .300 & 235.440 .000 & 0 \\
\hline 57 & 163.461 .500 & 109.486 .700 & 44.589 .000 & 2.890 .000 \\
\hline 58 & 182.558 .000 & 122.635 .700 & 66.679 .000 & \\
\hline 59 & 185.874 .500 & 164.541 .300 & 90.790 .000 & 3.692 .000 \\
\hline 60 & 195.442 .500 & 210.987 .000 & 90.221 .000 & 0 \\
\hline 61 & 550.192 .000 & 427.591 .000 & $(583.685 .000)$ & 0 \\
\hline 62 & 648.929 .000 & 450.997 .300 & $(569.515 .000)$ & 0 \\
\hline 63 & 655.375 .000 & 453.224 .300 & $(566.751 .000)$ & 0 \\
\hline 64 & 13.536 .500 .000 & 11.639 .300 .000 & 4.806 .000 .000 & 110.639 .300 \\
\hline 65 & 13.833 .000 .000 & 12.072 .300 .000 & 6.304 .000 .000 & 402.000 .000 \\
\hline 66 & 16.754 .500 .000 & 14.592 .000 .000 & 13.143 .000 .000 & 0 \\
\hline 67 & 15.377 .000 .000 & 16.769 .7000 .000 & 20.221 .000 .000 & 304.000 .000 \\
\hline 68 & 15.660 .000 .000 & 17.208 .7000 .000 & 22.103 .000 .000 & 500.000 .000 \\
\hline 69 & 26.925 .500 .000 & 21.577 .700 .000 & 35.269 .000 .000 & 10.499 .000 \\
\hline 70 & 29.941 .000 .000 & 23.525 .700 .000 & 41.113 .000 .000 & 10.002 .000 \\
\hline
\end{tabular}

